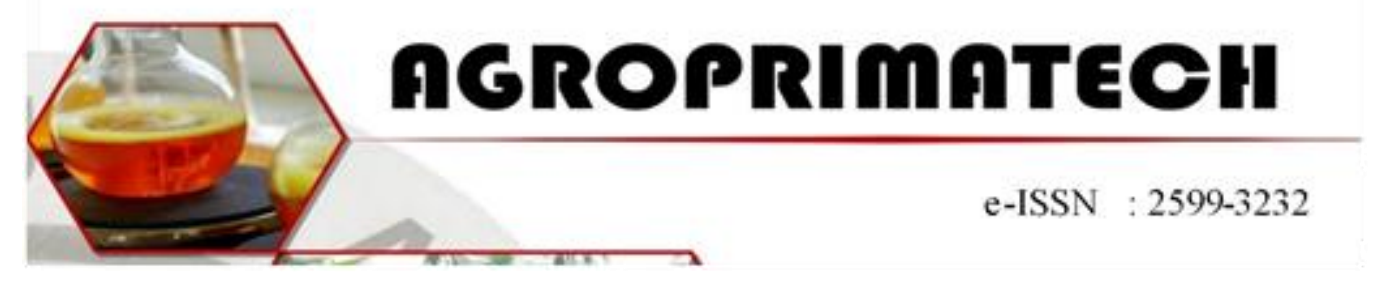

\title{
EFEKTIVITAS EKSTRAK BABADOTAN (Ageratum conyzoides L) DALAM PENGENDALIAN GULMA PADA PERKEBUNAN KELAPA SAWIT
}

\author{
SARI ANGGRAINI ${ }^{1}$ \\ ${ }^{1}$ Program Studi Agroteknologi, Universitas Prima Indonesia \\ Email : sarianggraini@unprimdn.ac.id
}

\begin{abstract}
ABSTRAK
Penelitian ini bertujuan untuk mengetahui efektivitas ekstrak babadotan (Ageratum conyzoides L.) dalam pengendalian gulma pada tanaman kelapa sawit dan untuk mengetahui kosentrasi ekstrak babadotan (Ageratum conyzoides L.) yang paling efektif dalam pengendalian gulma pada tanaman kelapa sawit. Metode penelitian menggunakan Rancangan Acak Kelompok non Faktorial dengan menggunakan uji ANAVA terdiri dari 11 variasi konsentrasi yaitu kontrol, $10 \%, 20 \%, 30 \%, 40 \%, 50 \%$, $60 \%, 70 \%, 80 \%, 90 \%, 100 \%$. Hasil vegetasi menunjukkan bahwa gulma yang di temukan terdapat 10 jenis spesies gulma yang terdiri dari Ottochloa nodusa, Boeraria alata, Ageratum conyzoides, Asystasia intrusa, Setaria barbata, Melastoma malabathricum, Diplazium esculentum, Mimosa pudica, Licopodium seanum, Cyclosorus aridus. Hasil pengamatan menunjukkan bahwa aplikasi pemberian ekstrak babadotan tidak memperlihatkan ciri fisik keracunan pada gulma di perkebunan kelapa sawit.
\end{abstract}

Kata Kunci : Gulma, Ekstrak, Babadotan, Herbisida, Nabati

\section{Pendahuluan}

Kehadiran gulma di perkebunan kelapa sawit dapat menurunkan produksi akibat bersaing dalam pengambilan air, hara, sinar matahari, dan ruang hidup. Gulma juga dapat menurunkan mutu produksi akibat terkontaminasi oleh bagian gulma, mengganggu pertumbuhan tanaman, menjadi inang bagi hama, mengganggu tataguna air, dan meningkatkan biaya pemeliharaan (Fauzi,Y., Y.E. dkk, 2014).

Pengendalian gulma merupakan suatu usaha untuk mengubah keseimbangan ekologis yang bertujuan untuk menekan pertumbuhan gulma, tetapi tidak berpengaruh negatif terhadap tanaman budidaya (Sukman, 2002). Moenandir (1993) menyatakan bahwa pengendalian gulma menggunakan herbisida yang terus menerus dapat mengakibatkan gulma menjadi toleran dan resisten pada suatu jenis herbisida tertentu. Gulma yang telah resisten akan tumbuh dan berkembang dan menyebabkan persaingan dengan tanaman utama (Pahan, 2008).

Herbisida nabati merupakan salah satu bentuk pengendalian gulma. Herbisisda ini erasal dari tumbuhan yang 
mengandung senyawa alelopati yang dapatmenghambat atau mematikan pertumbuhan tanaman sekitar. Bioherbisida ini ramah lingkungan karena tidak mengandung bahan berbahaya (Sukamto, 2007).

Salah satubioherbisida yang potensial adalah Babadotan (Ageratum conyzoides L). Babandotan telah terbukti memiliki alelopati efek pada sejumlah tanaman budidaya baik dari minyak atsiri dan ekstrak berair. Jenuh larutan encer dari precocene yang terisolasi dan dimurnikan telah dilaporkan memiliki efek penghambat yang signifikan pertumbuhan ryegrass. Potensi alelopati dari ekstrak berair dari organ babadotan yang berbeda (Shekar et al., 2012).

\section{Metode Penelitian}

Penelitian ini dilakukan di pusat Laboratorium Agro Terpadu Universitas Prima Indonesia Jalan Ayahanda, Laboratorium Pertanian USU, dan diaplikasikan di Perkebunan rakyat Desa Lengau Seprang, Tanjung Morawa Kabupaten Deli Serdang pada bulan April - Juni 2018. Alat yang digunakan dalam penelitian ini adalah knapsack $15 \mathrm{~L}$, ember, gelas ukur $1 \mathrm{~L}$, cangkul, dan tali rafia, toples, kain kasa, karet gelang, blender, gunting, saringan, semprotan, neraca analitik, peralatan gelas, pipet mikro, pinset, spatula, kertas saring, Aluminium Foil, Rotary Evaporator, dan kamera. Sedangkan bahan yang digunakan dalam penelitian ini adalah babadotan, ethanol $96 \%$, akuades.

\section{Rancangan Penelitian}

Penelitian ini menggunakan Rancangan Acak Kelompok (RAK) Non Faktorial, dengan perlakuan sebanyak 11 diulang sebanyak 3 kali.

Ekstrak Daun Babadotan (B) yaitu :

BO = Kontrol

B1 = Ekstrak daun babadotan $10 \%$ (10 $\mathrm{ml}+90 \mathrm{ml}$ akuades)
B2 = Ekstrak daun babadotan $20 \%$

(20 $\mathrm{ml}+80 \mathrm{ml}$ akuades)

B3 = Ekstrak daun babadotan $30 \%$

(30 $\mathrm{ml}+70 \mathrm{ml}$ akuades)

B4 = Ekstrak daun babadotan $40 \%$

(40 $\mathrm{ml}+60 \mathrm{ml}$ akuades)

B5 = Ekstrak daun babadotan $50 \%$

(50 $\mathrm{ml}+50 \mathrm{ml}$ akuades)

B6 = Ekstrak daun babadotan $60 \%$

(60 $\mathrm{ml}+40 \mathrm{ml}$ akuades)

B7 = Ekstrak daun babadotan $70 \%$

(70 $\mathrm{ml}+30 \mathrm{ml}$ akuades)

B8 = Ekstrak daun babadotan $80 \%$

(80 $\mathrm{ml}+20 \mathrm{ml}$ akuades)

B9 = Ekstrak daun babadotan $90 \%$

(90 $\mathrm{ml}+10 \mathrm{ml}$ akuades)

B10 = Ekstrak daun babadotan $100 \%$ (tanpa akuades)

Dimana :

Jumlah Perlakuan $\quad=\quad 11$

perlakuan

Jumlah Ulangan $\quad=\quad 3$

ulangan

Jumlah Plot $\quad=33$ plot

Luas Plot

$=1 \mathrm{~m} 2$

Pengelolahan data dengan menggunakan metode Rancangan Acak Kelompok (RAK) Non Faktorial dengan model linear.

$$
Y i j=\mu+T i+U j+\varepsilon i j
$$

Keterangan :

Yij = Tingkat kematian gulma yang diberi ekstrak babadotan

$\mu \quad=$ Rataan Umum

$\mathrm{Ti} \quad=$ Pengaruh perlakuan ke-i

$\mathrm{Uj} \quad=$ Pengaruh kelompok ke-j

عij = Pengaruh acak pada perlakuan ke-i dan kelompok ke-j

Data dianalisis dengan menggunakan ANAVA Penghitungan dilakukan dengan menggunakan komputer dengan program SAS 9.1.3 untuk mengetahui tingkat signifikan, apabila terdapat perbedaan yang nyata maka dilakukan uji lanjutan Duncan Multiple Range Test (DMRT) pada taraf $5 \%$. 
Agroprimatech

Vol. 3 No. 2, April 2020

Hasil dan Pembahasan

Analisa Vegetasi Gulma

Data yang telah di peroleh dari lapangan

kemudian dilakukan pengolahan data

dengan menghitung kerapatan,

kerapatan relatif, frekuensi, frekuensi

relatif, indeks nilai penting.

Tabel 1. Pengamatan analisis vegetasi gulma pada lahan penelitian

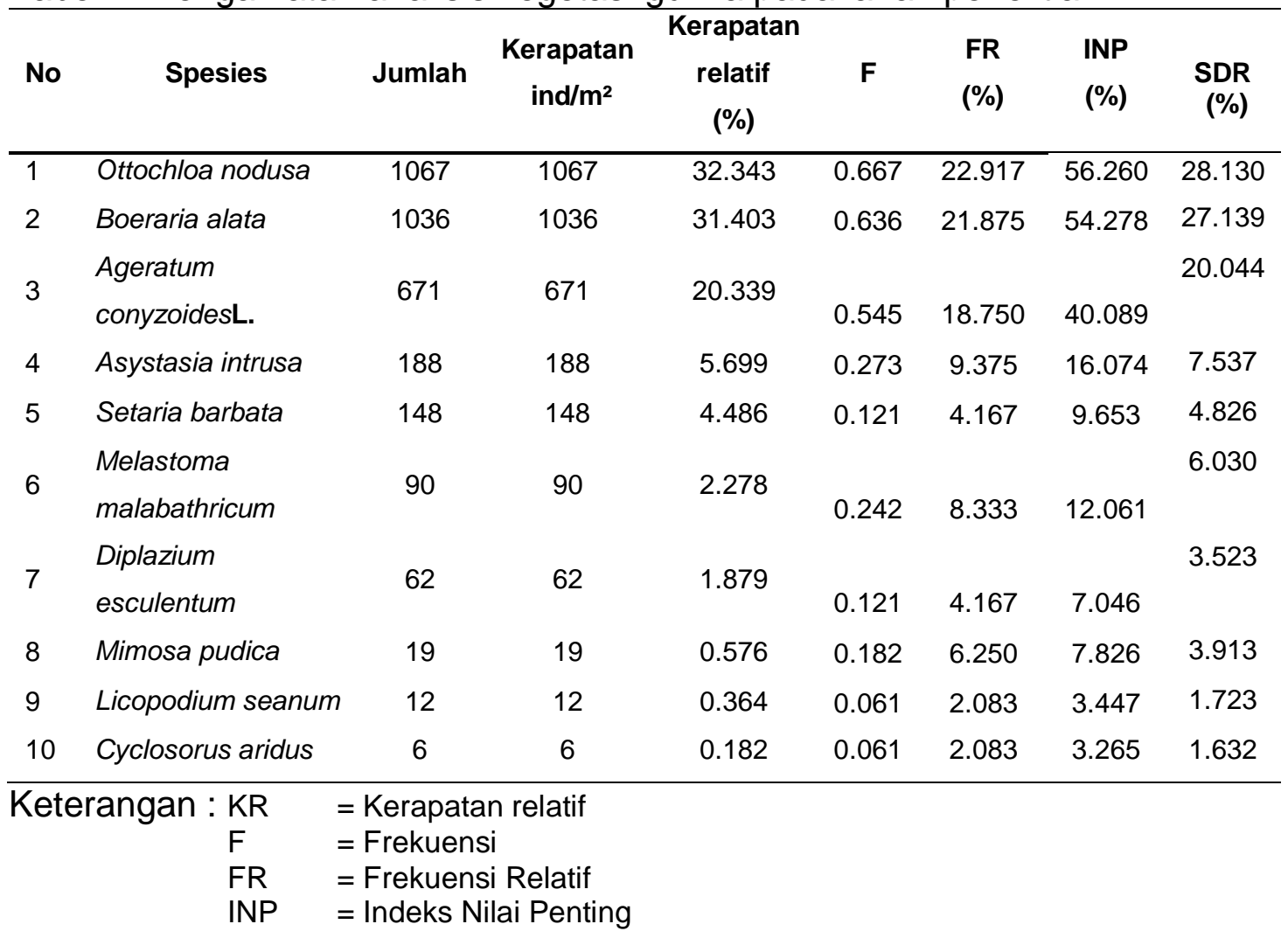


Agroprimatech

Vol. 3 No. 2, April 2020

Pada Tabel 1 menunjukkan bahwa gulma yang di temukan terdapat 10 jenis spesies gulma yang terdiri dari Ottochloa nodusa, Boeraria alata, Ageratum conyzoides, Asystasia intrusa, Setaria barbata, Melastoma malabathricum, Diplazium esculentum, Mimosa pudica, Licopodium seanum, Cyclosorus aridus. Indeks Nilai Penting dihitung berdasarkan penjumlahan nilai Kerapatan Relatif $(K R)$, Frekuensi Relatif (FR) dan Dominansi Relatif (DR). Indeks nilai penting gulma perkebunan kelapa sawit ditemukan nilai tertinggi adalah spesies Ottochloa nodusa dengan nilai $56.260 \%$. Jenis gulma ini memiliki peranan penting dibanding gulma lain, jenis gulma Ottochloa nodusa ini mampu bertahan hidup dan berkembang dapat dilihat dari jumlah nilai pentingnya.

\section{Presentase Kematian dan Pertumbuhan Gulma}

Presentase pengendalian gulma di amati setiap minggu pada 1 minggu setelah aplikasi (MSA) sampai 3 MSA. Hasil pengamatan presentase kematian gulma di perkebunan kelapa sawit pada minngu ke 1 masih belum ditemukan kematian pada gulma sampai pada minggu ke 3 , demikian juga dengan presentase pertumbuhan pada gulma setelah aplikasi perlakuan ekstrak babadotan. Aplikasi semua perlakuan mulai dari konsentrasi terendah (10\%) hingga konsentrasi tertinggi $(100 \%)$ tidak menunjukkan adanya tanda-tanda keracunan pada gulma di perkebunan kelapa sawit. Pada gambar 3 secara visual dapat di lihat gulma tidak mengalami tandatanda daun menguning dengan perlakuan konsentrasi $100 \%$ ekstrak babadotan.

Hal ini kemungkinan disebabkan oleh beberapa faktor, diantaranya adalah pengenceran dalam aplikasi, suhu penyimpan ekstrak babadotan pada saat
e-ISSN :2599-3232

sebelum diaplikasi, umur gulma, jenis gulma, dan cuaca di lapangan atau di perkebunan kelapa sawit.

Pada penelitian sebelumnya I sda bahwa biji gulma sengaja di tanam kemudian di berikan ekstrak babadotan dengan konsentrasi $20 \%$ mampu menekan pertumbuhan pada anakan gulma Paspalum conjugatum. Menurut Fitri et al., (2013) ekstrak babadotan berpengaruh nyata menurunkan perkecambahan dan pertumbuhan serta meningkatkan presentase kerusakan pada anakan gulma Chromolena odorata di perkebunan. Hal ini diduga karena adanya senyawa alelopati. Senyawa ini mampu menurunkan perkecambahan biji dan memperlambat waktu perkecambahan karena senyawa alelopati mengakibatkan terjadinya penghambatan aktivitas enzim-enzim yang melakukan degradasi cadangan makanan dalam biji sehingga energi tumbuh yang dihasilkan sangat rendah dan dalam waktu lebih lama menurunkan potensi perkecambahan.

Isda M. N., Fatonah S., dan Fitri R, 2013) menyatakan ekstrak n-heksan babadotan mengandung senyawa alkaloid dan terpenoid. Kandungan alelopati akan terakumulasi dalam sel dan bersifat racun yang dapat menjadikan sel-sel tidak elastis dan menghambat transfer ion terlarut melewati membran sel. Hambatan tersebut menyebabkan tanaman menjadi abnormal dan dapat menyebabkan kematian. Erida (2017) juga menyatakan pemberian $n$ heksan, etil asetat dan metanol babadotan pada berbagai konsentrasi berpengaruh terhadap presentase pengendalian gulma bayam duri. Hal ini diketahui kandungan bahan aktif babadotan (Ageratum conyzoides L.) adalah alkaloid, saponin, flavonoid seperti kuersetin, polifenol, sulfur dan tannin yang mempunyai sifat bioaktifitas alelopati. 
Agroprimatech

Vol. 3 No. 2, April 2020

Menurut Pebriani (2013) beberapa senyawa alelokimia pada tumbuhan dapat menghambat pembelahan sel, seperti senyawa fenol, terpenoid dan flavonoid seperti kuersetin. Adanya senyawa tersebut dapat menghambat sintesis asam ketogultarat yang merupakan prekusor protein, asam-asam amino dan ATP pada tanaman yang mengakibatkan terhambatnya pembesaran dan pembelahan sel. Alelopati yang dihasilkan tanaman dapat memberikan pengaruh yang bersifat merusak, menghambat, dan merugikan bagi tanaman dilingkungan sekitarnya (Yuliani, 2009). Master (2012) juga berpendapat bahwa alelopati mampu menurunkan perkecambahan biji dan memperlambat waktu perkecambahan, karena senyawa alelopati mengakibatkan terjadinya penghambatan aktivitas enzimenzim yang melakukan degradasi cadangan makanan dalam biji sehingga energi tumbuh yang dihasilkan sangat rendah dan dalam waktu lebih lama akan menurunkan potensi perkecambahan. Kemampuan tumbuhan babadotan yang bersifat alelopati diidentifikasi karena adanya 3 phenolic acid yaitu gallic acid, coumalid acid, dan protocatechuic acid yang dapat mengahambat beberapa gulma pada tanaman padi (Xuan et al., 2004).

Berdasarkan uraian di atas, maka kemungkin besar yang menyebabkan aplikasi ekstrak babadotan dalam penelitian ini tidak berpotensi untuk meracuni gulma di perkebunan kelapa sawit adalah akibat pengaruh umur gulma. Gulma yang diberikan ekstrak babadotan dari konsentrasi $10 \%$ hingga $100 \%$ di perkebunan kelapa sawit diperkirakan berumur sekitar $3-4$ bulan. Sementara dari beberapa hasil penelitian menunjukkan bahwa ekstrak babadotan berpotensi mematikan gulma pada umur anakan. Oleh karena itu, untuk dapat mengendalikan
e-ISSN :2599-3232

gulma diperkebunan kelapa sawit maka ekstrak babadotan kemungkinan akan berpotensi mematikan gulma apabila dicampurkan dengan herbisida.

Kemudian dalam penelitian ini jenis gulma yang lebih dominan dilapangan adalah gulma berdaun lebar yaitu Boeraria alata, Ageratum conyzoides L, Asystasia intrusa, Melastoma malabathricum, yang pada umumnya dikendalikan dengan menggunakan herbisida dengan konsentrasi standar. Sedangkan aplikasi ekstrak babadotan meskipun pada konsentrasi yang sangat tinggi (100 \%) tidak mampu untuk meracuni jenis gulma tersebut.

\section{Kesimpulan}

Aplikasi ekstrak babadotan mulai dari kosentrasi $10 \%$ hingga $100 \%$ tidak memperlihatkan ciri fisik keracunan pada gulma di perkebunan kelapa sawit. Jenis gulma yang mendominasi di perkebunan kelapa sawit adalah Boeraria alata, Ageratum conyzoides L., Asystasia intrusa, dan Melastoma malabathricum.

\section{DAFTAR PUSTAKA}

Alfandi dan Dukat. 2007. Respon Pertumbuhan dan Produksi Tiga Kultivar Kacang Hijau (Vignaradiata L.) Terhadap Kompetisi dengan Gulma pada Dua Jenis Tanah. Jurnal Agrijati, 6(1) : 26-29.

Ardi. 1999. Potensi Alelopati Akar Rimpang Alang-Alang (Imperata cylindrica L.) Terhadap Mimosa pudica L. Stigma, 7 (1) : 66-68.

Amalia, P. 2009. Efikasi herbisida kalium glifosat (touchdown $450 \mathrm{sl}$ ) terhadap gulma pada budidaya karet (Hevea 
Agroprimatech

Vol. 3 No. 2, April 2020

brasiliensis [Muell.] Arg.) dan kelapa sawit (Elaeis guineensis Jacq.) menghasilkan. Skripsi. Fakultas Pertanian, Universitas Lampung. 134.

Barus, E. 2003. Pengendalian Gulma di Perkebunan, Efektivitas dan Efisiensi Aplikasi Herbisida. Yogyakarta (ID) : Kanisius..

Direktorat Jenderal Perkebunan. 2016. Buku Statistik Kelapa Sawit. Dirjen pertanian.go.id. 2016.

Djojosumarto, P. 2008. Pestisida dan Aplikasinya. PT Agro Media Pustaka. Jakarta. P. 23-24.

Erida G. 2017. Uji Aktivitas bioherbisida ekstrak n-heksana, etil asetat, dan metanol tumbuhan babadotan (Ageratum conyzoides L.) terhadap pertumbuhan bayam duri (Amaranthus spinosus L.). Skripsi. UNSIYAH.

Fauzi,Y., Y.E. Widyastuti, I. Satyaawibawa, dan R.H. Paeru. 2014. Kelapa Sawit. Penebar Swadaya. Jakarta. 234.

Fitri R., Isda M. N., dan Fatonah S. 2013. Uji ekstrak daun gulma babadotan (Ageratum conyzoides L.) terhadap perkecambahan dan pertubuhan gulma Chromolena odorataL. Karya IImiah.

Fitri, Dera Satria., Syam Zuhri., Solfiyeni. 2014. Komposisi dan struktur gulma pada fase vegetatif padi sawah (Oryza sativa L.) di Nagari Singkarak Kabupaten Solok Sumatera Barat. Jurnal Biologi 3(1): 68-72
e-ISSN : 2599-3232

Fitriani, A. 2004. Kandungan Senyawa Dalam Kalus Ageratum conyzoides L. Jurnal Penelitian, 2(1).

Isda M. N., Fatonah S., dan Fitri R. 2013. Potensi ekstrak daun gulma babadotan (Ageratum conyzoides L.) terhadap perkecambahan dan pertumbuhan Paspalum conjugatum Berg. Jurnal Biologi. 6(2).

Lutfy, D.C., Kholqin J., Andi, A.A.A, dan Nur, A. 2015. Pemanfaatan seresah daun bambu (Dendrocalamus asper)sebagai bioherbisida pengendali gulma yang ramah lingkungan. UD Gontor.

Madhumathy A.P, Aivazi A.A, Vijayan. (2007). Larvicidal efficacy of capsicum annum against anopheles stephensi and culex quin quefasciatus. Short Research Communications. J Vect Borne.

Moenandir, J. 1988. Pengantar ilmu dan pengendalian gulma. Rajawali Press: Jakarta.

Moenandir, J. 1993. Persaingan tanaman budidaya dan gulma. Raja Grafindo Persada. Jakarta. 101.

Pahan, I. 2008. Panduan Lengkap Kelapa Sawit : Manajemen agribisnis dari hulu hingga hilir. Penebar Swadaya. Jakarta. 412.

Pebriani, Riza L, Mukarlina. 2013. Potensi ekstrak daun sembung rambat (Mikania micrantha) sebagai bioherbisida terhadap gulma maman ungu dan rumput bahia. Protobiont. 2 (2): 32-38 
Agroprimatech

Vol. 3 No. 2, April 2020

Sembodo, D.R.J. 2010. Gulma dan pengelolaannya. Graha IImu. Yogyakarta.168.

Shekar. C. T. \& Goyal Anju. (2014). A comprehensive review on Ageratum conyzoides Linn.(Goat weed). Rajasthan, India.

Sindel, B., \& Coleman, M. (2010). Weed Detection and Control on Small Farms. Australia Government. Australia.

Sukman, Y dan Yakup. 1995. Gulma dan pengendaliannya. PT Rajawali Press. Jakarta

Sukamto. 2007. Babadotan (Ageratum conyzoides) tanaman multi fungsi. Warta Puslitbangbun, 13 (3).

Sunarko. 2009. Petunjuk Praktis budidaya dan pengelolaan kelapa sawit. Agro Media Perpustakaan, Jakarta.

Suwarto, Y., Octavianty, dan S. Hermawati. 2014. Top 15 Tanaman perkebunan. Penebar Swadaya. Jakarta. 316.
e-ISSN :2599-3232

Sukman, Y dan Yakub. 2002. Gulma dan teknik pengendaliannya. Edisi 2. PT Radja Grafindo Persada. Jakarta.

Tim Bina Karya Tani. 2009. Pedoman bertanam kelapa sawit. Yrama Widya. Bandung. 128.

Tjitrosoedirdjo, S., I.S. Utomo, dan J. Wiroatmodjo. 1984. Pengelolaan gulma di perkebunan. PT Gramedia. Jakarta. 210.

Wattimena, G. A. (1987). Zat Pengatur Tumbuh. PAU Bioteknologi IPB. Bogor.

Xuan, T.D., N.H. Honh, T. Ediji, and T.D. Khanh. 2004. Paddy weed control by higher plants from Southeast Asia. Crop. Prot. Journal. 23: 255-26.

Yuliani, Rahayu. Y.S., Ratnasari,E., \& Mitarlis. (2009). Potensi senyawa alelokemi daun Pluchea indica (L.) Less. sebagai penghambat perkecambahan biji gulma secara hayati. Berk. Penel. Hayati Edisi Khusus: 3A, 69-73. 